\title{
PENINGKATAN KREATIVITAS PEMECAHAN MASALAH MELALUI METODE "WHAT'S ANOTHER WAY" PADA MATERI BANGUN DATAR SISWA KELAS VII SMP
}

\author{
WARLI \\ EPA YULIANA \\ warli66@gmail.com \\ Universitas PGRI Ronggolawe Tuban \\ Jl. Manunggal 61 Tuban, Jawa Timur
}

\begin{abstract}
This study aims to describe the increase in students' creativity in solving mathematical problems and student response after learning the methods of what's another way. To achieve these objectives with the class action research conducted qualitative descriptive approach. Research subjects were students in grade VII SMP N Semanding, Tuban. Data collection techniques, to find out the creativity problem solving is done through task-based interviews. To study the response of students is done through questionnaire responses of students. Analysis of data creativity problem solving creativity refers to the three indicators, namely fluency, flexibility, and novelty. The results showed that subjects with good levels of mathematical ability, moderate and less intelligent, creativity in solving problems increased after the applied method of what's another way. The quality of students' creativity in solving the problem tends to be low. Being the response of students towards learning by using the "what's another way" is very positive.
\end{abstract}

Kata kunci: creativity, problem solving, what's another way, methods.

\section{PENDAHULUAN}

Pendidikan karakter beberapa tahun ini menjadi topik yang menarik untuk didiskusikan. Berbagai tema seminar, simposium, dan kegiatan ilmiah lainnya selalu mengambil tema tentang pendidikan karakter. Sesungguhnya pendidikan karakter bukanlah hal baru dalam sistem pendidikan nasional, karena tujuan pendidikan nasional dalam semua undang-undang yang pernah berlaku (UU 4/1950; 12/1954; 2/89) dengan rumusannya yang berbeda secara substantif memuat pendidikan karakter. Bahkan secara historis filosofis "Bapak" Pendidikan Nasional, Ki Hadjar Dewantara, menyatakan bahwa “...pendidikan merupakan daya upaya untuk memajukan bertumbuhnya budi pekerti (kekuatan batin, karakter), pikiran (intellect) dan tubuh anak. Wiranataputra (2010) menjelaskan bahwa secara psikologis dan sosial kultural pembentukan karakter dalam diri individu merupakan fungsi dari seluruh potensi individu manusia (kognitif, afektif, konatif, dan psikomotorik) dalam konteks interaksi sosial kultural (dalam keluarga, satuan pendidikan, dan masyarakat) dan berlangsung sepanjang hayat. Konfigurasi karakter dalam konteks totalitas proses psikologis dan sosial-kultural tersebut dapat dikelompokkan dalam: Olah Hati (Spiritual and emotional development), Olah Pikir (intellectual development), Olah Raga dan Kinestetik (Physical and kinestetic development), dan Olah Rasa dan Karsa (Affective and Creativity development). Sangat jelas, bahwa pengembangan kreativitas merupakan bagian dalam pembentukan karakter diri siswa.

Kurikulum 2006 memberikan kesempatan kepada sekolah untuk mengembangkan pendidikan yang ada di sekolah masing-masing. Hal ini berarti guru mata pelajaran diberikan kebebasan untuk menerapkan metode pembelajaran yang sesuai dengan kemampuan yang dimiliki oleh siswa dan masalah yang dipelajari. Selain itu, juga mengamanatkan pentingnya mengembangkan kreativitas siswa dan kemampan berpikir 
kreatif melalui aktivitas-aktivitas kreatif dalam pembelajaran yang diarahkan untuk mendorong atau memunculkan kreativitas siswa yang bertujuan untuk mengembangkan kemampuan memecahkan masalah. Tetapi dalam pelaksanaan pembelajaran di kelas guru lebih sering menggunakan tes tertulis dengan soal-soal yang rutin daripada menggunakan soal-soal yang mengandung pemecahan masalah. Ini berarti kemampuan pemecahan masalah pada siswa masih kurang dikembangkan.

Pemecahan masalah sejak tahun 1980 an hingga sekarang diakui merupakan hal penting yang harus dikembangkan dalam pembelajaran. LeBlanc, Proudfit \& Putt (1980) menjelaskan bahwa mengembangkan keterampilan memecahkan masalah telah lama diakui sebagai tujuan penting di program matematika sekolah dasar. Davis \& McKillip (1980) juga mengatakan bahwa kemampuan memecahkan masalah merupakan salah satu tujuan yang paling penting dalam kajian matematika. Pemecahan masalah dalam matematika, sains, bisnis, dan kehidupan sehari-hari merupakan tujuan pokok dalam belajar matematika.

Pemecahan masalah, diartikan sebagai suatu proses yang dilakukan oleh siswa untuk menemukan jawaban terhadap pertanyaan (masalah) yang dihadapi. Tahap-tahap pemecahan masalah meliputi: memahami masalah, menentukan rencana pemecahan masalah, mengerjakan sesuai rencana, dan memeriksa kembali jawaban yang diperoleh beserta langkah-langkah memperoleh jawaban tersebut. Masalah sendiri diartikan sebagai pertanyaan yang menghadirkan suatu tantangan (challenge) yang tidak dapat dipecahkan dengan suatu prosedur rutin yang sudah diketahui siswa. (Warli, 2010)

Pemecahan masalah merupakan aktivitas mental tingkat tinggi, sehingga pengembangan keterampilan pemecahan masalah dalam pembelajaran tidak mudah. LeBlanc, Proudfit \& Putt (1980) mengatakan bahwa pembelajaran pemecahan masalah telah diakui sebagai tugas yang sulit. Polya (1973) mengatakan bahwa sesungguhnya kemampuan memecahkan masalah ada pada ide penyusunan rencana. Demikian juga Orton (1992) menyebutkan bahwa tahap-tahap yang sangat sulit dan rumit adalah tahap 2 (menentukan rencana pemecahan masalah), dan tahap 3 (mengerjakan), terutama tahap kedua di mana kreativitas, dayatemu, dan pengertian mendalam sangat diperlukan. Berdasarkan pendapat tersebut, kreativitas mempunyai peran penting dalam pemecahan masalah khususnya dalam merencanakan pemecahan masalah.

Kreativitas adalah suatu kemampuan individu untuk menghasilkan ide-ide atau gagasan-gagasan yang "baru" untuk memecahkan masalah secara fasih, dan fleksibel. Kefasihan dalam pemecahan masalah mengacu pada keragaman (bermacam-macam) jawaban masalah yang dibuat siswa dengan betul. Fleksibilitas dalam pemecahan masalah mengacu pada kemampuan siswa memecahkan masalah dengan berbagai cara yang berbeda-beda; siswa mampu mengubah suatu pemecahan masalah menjadi pemecahan lain yang berbeda. Kebaruan dalam pemecahan masalah mengacu pada kemampuan siswa untuk menjawab masalah dengan beberapa jawaban yang berbeda-beda tetapi bernilai betul atau satu jawaban yang tidak biasa dilakukan oleh individu (siswa) pada tahap perkembangan intelektual mereka atau tingkat pengetahuan mereka. Beberapa jawaban dikatakan berbeda, apabila jawaban tampak berlainan dan tidak mengikuti pola tertentu, misal gabungan dari beberapa bangun datar. Jadi kreativitas pemecahan masalah dapat diartikan sebagai kemampuan individu untuk menghasilkan ide-ide atau gagasan-gagasan yang "baru" dalam menemukan suatu cara/alat untuk memperoleh jawaban terhadap pertanyaan (masalah) secara fasih, dan fleksibel (Warli, 2010)

Permasalahannya adalah bagaimana mendesain pembelajaran yang dapat meningkatkan kreativitas siswa dalam memecahkan masalah. Salah satu pendekatan yang pernah penulis lakukan adalah pendekatan pembelajaran dengan menggunakan soal terbuka. Pendekatan pembelajaran dengan menggunakan soal terbuka (open ended 
approach) merupakan salah satu pendekatan yang dapat meningkatkan kreativitas siswa (Warli, 2007). Pada penelitian ini peneliti mencoba menggunakan metode pembelajaran "What's Another Way" yang dikemukakan oleh Stephen Krulik \& Jesse A. Rudnick. Metode pembelajaran "What's Another Way" merupakan metode pembelajaran yang memberikan tantangan kepada siswa setelah menjawab sebuah masalah. Tantangan ini membuat siswa berpikir kembali untuk mencari alternatif jawaban lain, selain jawaban yang telah mereka buat. Krulik \& Rudnick (1999) menyatakan, "... the students are forced to think of other ways to approach the problem. This activity is an excellent way to practice creative thinking. Although contrived, the following problem elicits solutions that provide insight into students' reasoning."

Pertanyaan penelitian ini adalah: a) Bagaimana peningkatan kreativitas siswa kelas VII SMP Negeri 2 Semanding, Tuban dalam memecahkan masalah setelah diajarkan melalui metode "what's another way"? b) Bagaiamana respon siswa kelas VII SMP Negeri 2 Semanding, Tuban setelah diajarkan melalui metode "what's another way"?

Berdasarkan pertanyaan tersebut, tujuan penelitian ini adalah a) mendeskripsikan secara rinci peningkatan kreativitas siswa dalam memecahkan masalah setelah menggunakan metode "what's another way" pada materi bangun datar siswa kelas VII SMP Negeri 2 Semanding, Tuban. b) mendeskripsikan respon siswa kelas VII SMP Negeri 2 Semanding, Tuban setelah menggunakan metode "what's another way".

\section{TINJAUAN PUSTAKA}

\section{Pemecahan Masalah}

Polya (1980) menjelaskan bahwa memecahkan masalah adalah menemukan cara/alat untuk menjawab yang ditanyakan sampai akhirnya tersusun jawaban dengan jelas. Memecahkan masalah berarti menemukan suatu cara, mencari jalan ke luar dari kesulitan, menemukan cara mengatasi rintangan, untuk mencapai tujuan yang diinginkan, dengan alat yang sesuai. Orton (1992) menyatakan, "Problem-solving is now normally intended to imply a process by which the learner combines previously learned elements of knowledge, rules, techniques, skills and concepts to provide a solution to a novel situation". Pemecahan masalah adalah proses yang dilakukan siswa dalam mengkombinasikan komponen-komponen pengetahuan, aturan-aturan, teknik-teknik, keterampilan-keterampilan dan konsep-konsep untuk menghasilkan pemecahan situasi baru.

Mengacu pada pendapat di atas, dapat dikatakan bahwa pemecahan masalah adalah suatu proses yang dilakukan oleh siswa untuk menemukan jawaban terhadap pertanyaan (masalah) yang dihadapi. Proses menemukan jawaban terhadap masalah dengan cara mengkombinasikan komponen-komponen pengetahuan, aturan-aturan, teknik-teknik, keterampilan-keterampilan dan konsep-konsep.

Setiap pertanyaan tidak selalu menjadi masalah bagi siswa. Menurut Cooney, et al. (1975: 242) "... for a question to be a problem, it must present a challenge that cannot be resolved by some routine procedure known to the student." Pertanyaan merupakan masalah, jika pertanyaan itu menghadirkan suatu tantangan (challenge) yang tidak dapat dipecahkan dengan suatu prosedur rutin yang sudah diketahui siswa. Pernyataan ini menunjukkan bahwa tidak setiap pertanyaan merupakan masalah, bergantung kepada siswanya. Hal ini dipertegas oleh Schoenfeld (1985) yang menyatakan, "The difficulty with defining the term problem is that problem solving is relative" Istilah masalah dalam pemecahan masalah adalah relatif. Hudojo (2001) menjelaskan bahwa pertanyaan akan merupakan masalah jika seseorang tidak mempunyai aturan/hukum tertentu yang segera dapat dipergunakan untuk menemukan jawaban pertanyaan tersebut. Pertanyaan 
merupakan masalah, bergantung kepada individunya; pertanyaan merupakan suatu masalah bagi siswa, tetapi mungkin bukan merupakan masalah bagi siswa lain. Merujuk pada beberapa pengertian masalah di atas, dapat disimpulkan bahwa masalah adalah pertanyaan yang menghadirkan suatu tantangan (challenge) yang tidak dapat dipecahkan dengan suatu prosedur rutin yang sudah diketahui siswa.

Polya (1973) menjelaskan bahwa pemecahan masalah memuat empat tahap (fase) pemecahan, yaitu: 1) memahami masalah (understanding the problem); 2) menentukan rencana (devising a plan); 3) mengerjakan sesuai rencana (carrying out the plan); 4) melakukan pemeriksaan kembali (looking back). Fase pertama adalah memahami masalah, siswa tidak mungkin dapat memecahkan masalah dengan betul, bila tidak memahami masalah yang diberikan. Setelah siswa memahami masalah dengan betul, dilanjutkan pada fase kedua, yaitu menentukan rencana pemecahan masalah. Fase kedua ini sangat bergantung pada pengalaman siswa dalam memecahkan masalah. Pada umumnya, semakin bervariasi pengalaman yang dimiliki siswa, ada kecenderungan siswa lebih kreatif dalam menentukan rencana pemecahan masalah. Bila penyusunan rencana telah dibuat, selanjutnya dilakukan pemecahan masalah sesuai rencana. Fase terakhir adalah melakukan pengecekan terhadap apa yang telah dilakukan mulai fase pertama sampai fase ketiga.

\section{Kreativitas}

Shaw \& Simon (Krutetskii, 1976) memberikan indikator berpikir kreatif, yaitu 1) produk aktivitas mental mempunyai sifat kebaruan (novelty) dan bernilai baik secara subjektif maupun objektif; 2) proses berpikir baru, yaitu suatu transformasi ide-ide awal yang diterimanya maupun yang ditolak; 3) proses berpikir memiliki ciri adanya sebuah motivasi yang kuat dan stabil, serta dapat diamati melebihi waktu yang dipertimbangkan atau dengan intensitas yang tinggi. Travers (1979: 349) mendefinisikan berpikir kreatif merupakan suatu proses berpikir yang mengkonstruk jawaban atau ide asli. Sedang Perkin (Marzano, 1988) mendefinisikan berpikir kreatif sebagai hasil tindakan internal (mengambil keputusan, merumuskan hipotesis, menarik kesimpulan), dan eksternal (membuat analogi, memiliki gagasan baru untuk eksperimen) berpikir yang konsisten, bermakna berbicara hanya dalam garis besarnya saja, asli dan tepat sesuai dengan yang dipersyaratkan.

Berpikir kreatif pada dasarnya merupakan perpaduan antara berpikir logis dan berpikir divergen yang didasarkan pada intuisi. Seseorang waktu berpikir kreatif dalam memecahkan masalah, berpikir divergen akan menghasilkan banyak ide dan kebenaran berpikir tersebut akan ditentukan oleh berpikir logisnya. Krulik dan Rudnick (1999) menjelaskan, "Creative thinking is thinking that is original and reflective and that produces a complex product. It includes synthesizing ideas, generating new ideas, and determining their effectiveness. Creative thinking includes the ability to make decisions and usually involves the generation of some new end product." Kutipan tersebut menunjukkan bahwa berpikir kreatif adalah berpikir yang bersifat asli dan reflektif dan yang menghasilkan suatu produk yang kompleks. Berpikir tersebut meliputi mensintesis ide-ide, membangun ide-ide baru dan menentukan efektivitasnya. Berpikir kreatif meliputi kemampuan untuk membuat keputusan dan biasanya melibatkan pembuatan suatu produk akhir yang baru. Sedang Furinghetti \& Morselli (2004) menyatakan. "... creative thinking, whose key aspects are 'the ability to overcome fixations in mathematical problem-solving and the ability for divergent production within the mathematical situation'." Aspek kunci berpikir kreatif adalah kemampuan mengatasi fiksasi dalam memecahkan masalah matematika dan kemampuan untuk menghasilkan sesuatu yang divergen di dalam situasi matematika. Mengacu pada kedua pendapat 
tersebut, untuk meningkatkan berpikir kreatif siswa dalam matematika harus mampu mengatasi fiksasi dan menghasilkan pemecahan yang divergen.

Kreativitas mempunyai pengertian beragam. Pengertian kreativitas tergantung bagaimana orang mendefinisikannya, tidak ada satu definisipun yang dianggap mewakili pemahaman yang beragam tentang kreativitas. Supriadi (1994: 6) menjelaskan ada dua alasan: pertama, sebagai "konstruk hipotesis", kreativitas merupakan ranah psikologis yang kompleks dan multidimensional, yang mengundang berbagai tafsiran yang beragam. Kedua, definisi-definisi kreativitas memberikan tekanan yang berbeda-beda, tergantung dasar teori yang menjadi acuan pembuat definisi.

Semiawan (1990: 7) mengatakan bahwa kreativitas adalah kemampuan memberikan gagasan-gagasan baru dan menerapkannya dalam pemecahan masalah. Perkins (1991) juga menjelaskan kreativitas merupakan kemampuan khusus atau talenta, dan produk yang kreatif tidak bergantung kepada satu sifat saja, yaitu ide baru. Secara singkat komponen-komponen yang mempengaruhi antara lain: a) berpikir kreatif melibatkan sisi seni dan standar praktis, b) berpikir kreatif bergantung pada perhatian terhadap tujuan dan hasil, c) berpikir kreatif lebih banyak bergantung kepada mobilitas dari pada kepada kelancaran, d) berpikir kreatif tidak hanya objektif tapi juga subjektif, e) berpikir kreatif lebih banyak bergantung kepada motivasi intrinsik daripada motivasi ekstrinsik.

Hurlock (1999: 4) menjelaskan kreativitas merupakan kemampuan seseorang untuk menghasilkan komposisi produk atau gagasan apa saja yang pada dasarnya baru dan sebelumnya tidak dikenal pembuatnya. Hal tersebut berupa kegiatan imajinasi atau sintesis pemikiran yang hasilnya bukan hanya perangkuman. Kegiatan ini mungkin mencakup pembentukan pola baru dan gabungan informasi yang diperoleh dari pengalaman sebelumnya dan pecangkokan hubungan lama ke situasi baru mungkin mencakup pembentukan korelasi baru. Definisi-definisi ini sebagian besar penekanannya pada produk dan proses.

Ada beberapa definisi kreativitas yang berdasarkan aspek proses satu di antaranya dikemukakan oleh Torrance (Munandar, 1999) yaitu, “... the process of 1) sensing difficulties, problems, gaps in information, missing elements, something asked; 2) making guesses and formulating hypotheses about these deficiencies; 3) evaluating and testing these guesses and hypotheses; 4) possibly revising and retesting them; and finally 5) communicating the results" Definisi Torrance ini meliputi seluruh proses kreatif dan ilmiah mulai dari menemukan masalah sampai dengan penyampaian hasil. Definisi kreativitas yang didasarkan pada aspek produk antara lain dikemukakan oleh Barron (Munandar, 1999) bahwa kreativitas adalah kemampuan untuk menghasilkan/menciptakan sesuatu yang baru. Definisi kreativitas berdasarkan pada aspek dorongan (press) dikemukakan oleh Simpson (Munandar, 1999) bahwa kemampuan kreatif dirumuskan sebagai "the initiative that one manifests by his power to break away from the usual sequence of thought." Jadi kemampuan kreatif dirumuskan sebuah inisiatif seseorang yang diwujudkan oleh kemampuannya untuk mendobrak pemikiran yang biasa. Kreativitas tidak berkembang dalam budaya yang terlalu menekankan cara saling bantu dan tradisi yang kurang terbuka terhadap perubahan atau perkembangan baru.

Dari beberapa definisi kreativitas di atas sebagian besar mengarah pada proses atau produk yang baru. Dalam penelitian ini mengarah pada pemecahan masalah dalam bidang datar, sehingga pengertian kreativitas ditekankan pada aspek produk dan proses pemecahan masalah untuk menghasilkan pemecahan yang baru dan berguna. Kreativitas matematika menurut Krutetskii (1976) merupakan kemampuan (abilities) siswa yang berhubungan dengan suatu penguasaan kreatif mandiri (independent) matematika di 
bawah pengajaran matematika, formulasi mandiri masalah-masalah matematik yang tidak rumit (uncomplicated), penemuan cara-cara dan sarana dari pemecahan masalah, penemuan bukti-bukti teorema, penemuan bentuk deduksi mandiri rumus-rumus dan penemuan metode-metode asli pemecahan masalah non standar.

\section{Metode What's Another Way}

Tujuan siswa dilatih menyelesaikan masalah menurut Russefendi (1988:341) salah satunya adalah untuk meningkatkan motivasi dan menumbuhkembangkan sikap kreatif pada siswa. Russefendi juga menjelaskan untuk menyaring individu yang kreatif sebaiknya menggunakan pertanyaan-pertanyaan terbuka (divergen), yaitu pertanyaan yang jawabannya bisa lebih dari sebuah dan tidak bisa diperkirakan sebelumnya. Oleh sebab itu, siswa perlu diajarkan pemecahan masalah. Salah satu metode pembelajaran yang mungkin dapat meningkatkan kreativitas siswa dalam pemecahan masalah adalah dengan menerapkan metode what's another way. What's another way adalah suatu metode atau cara penyelesaian yang menuntut siswa untuk memecahkan masalah dengan menggunakan lebih dari satu cara dan tidak menutup kemungkinan siswa akan mempeoleh jawaban yang beragam dan berbeda. Krulik dan Rudnick (1999:139) menyebutkan bahwa what's another way sebagai langkah refleksi atau sebagai kelanjutan langkah dari langkah terakhir polya, yaitu memeriksa kembali (looking back). Berikut langkah-langkah metode what's another way dalam memecahkan masalah:

Tabel 1. Langkah-langkah Metode What's Another Way

\begin{tabular}{|c|c|c|}
\hline No & Langkah-Langkah & Kegiatan Pembelajaran \\
\hline 1 & Memahami masalah & $\begin{array}{l}\text { Dalam langkah ini dimulai dengan } \\
\text { membaca soal dengan seksama, dengan } \\
\text { pengenalan apa yang diketahui dan apa } \\
\text { yang tidak diketahui, data yang tersedia. }\end{array}$ \\
\hline 2 & $\begin{array}{l}\text { Menyusun rencana } \\
\text { penyelesaian }\end{array}$ & $\begin{array}{l}\text { Langkah kedua yaitu menyusun rencana } \\
\text { penyelesaian dapat dengan menggunakan } \\
\text { banyak strategi dan teknik yang digunakan } \\
\text { atau dengan membuat langkah-langkah } \\
\text { yang sistematis. }\end{array}$ \\
\hline 3 & Melaksanakan rencana & $\begin{array}{l}\text { Jika dalam langkah kedua telah berhasil } \\
\text { dirinci dengan lengkap, maka dalam } \\
\text { pelaksanaan rencana penyusunan soalnya } \\
\text { menajdi bentuk yang sederhana dan } \\
\text { melakukan perhitungan yang diperlukan. }\end{array}$ \\
\hline 4 & Memeriksa kembali & $\begin{array}{l}\text { Pada langkah ini setelah jawaban } \\
\text { ditemukan, diperiksa kembali cara } \\
\text { pemecahan masalah, apakah jawaban yang } \\
\text { diperoleh sudah tepat. }\end{array}$ \\
\hline 5 & $\begin{array}{l}\text { Refleksi } \\
\text { tantangan) }\end{array}$ & $\begin{array}{l}\text { Langkah kelima adalah langkah terakhir } \\
\text { what's another way yaitu menjawab } \\
\text { tantangan dari masalah yang ada dengan } \\
\text { mencari cara lain untuk menemukan } \\
\text { jawaban itu. }\end{array}$ \\
\hline
\end{tabular}


Menurut hasil penelitian (Warli, 2011) tentang peningkatan kreativitas mahasiswa dalam membuktikan validitas argumen melalui metode pembelajaran "what's another way" diperoleh hasil sebagai berikut. Siklus pertama, menunjukkan bahwa mahasiswa yang tidak kreatif sebanyak $42,1 \%$, mahasiswa yang kurang kreatif sebanyak $31,6 \%$, mahasiswa yang cukup kreatif sebanyak $13,2 \%$, dan mahasiswa yang kreatif sebanyak $13,2 \%$. Siklus kedua, menunjukkan bahwan mahasiswa yang tidak kreatif sebanyak $28,9 \%$, mahasiswa yang kurang kreatif sebanyak $21,05 \%$, mahasiswa yang cukup kreatif sebanyak 28,9\%, mahasiswa yang kreatif sebanyak 18,4\%, dan mahasiswa yang sangat kreatif sebanyak $2,6 \%$. Siklus ketiga, menunjukkan bahwa mahasiswa yang tidak kreatif sebanyak 28,9\%, mahasiswa yang kurang kreatif sebanyak 13,2\%, mahasiswa yang cukup kreatif sebanyak 34,2\%, mahasiswa yang kreatif sebanyak 21,05, dan mahasiswa yang sangat kreatif sebanyak $2,6 \%$. Secara umum metode pembelajaran "what's another way" dapat meningkatkan kreativitas mahasiswa dalam membuktikan validitas argumen. Kesulitan utama dalam membuktikan validitas argumen adalah sebagai berikut: a) penggunaan aturan-aturan pembuktian argumen, dan b) gagasan menyusun rencana pembuktian.

\section{METODE}

Penelitian ini merupakan penelitian tindakan kelas dengan pendekatan deskriptif yang bersifat kualitatif yang berusaha mendeskripsikan peningkatan kreativitas siswa dalam memecahkan masalah setelah menggunakan metode what's another way. Penelitian ini menggunakan satu kelas. Subjek penelitian ini adalah siswa kelas VII.E SMP Negeri 2 Semanding, Tuban Tahun Pelajaran 2010/2011 yang berjumlah 41 siswa. Sedangkan jumlah subjek yang dianalisis datanya sebanyak 6 siswa yang telah dikonsultasikan pada guru bidang studi matematika untuk meminta pertimbangan dengan melihat tingkat kemampuan matematika yang berbeda-beda, yaitu pandai, sedang, kurang pandai dan kemampuan siswa dalam mengkomunikasikan jawaban secara lisan maupun tulisan dengan baik. Instrumen penelitian ini berupa tes/tugas berbentuk pemecahan masalah, pedoman wawancara dan angket respon siswa. Tes kreativitas pemecahan masalah berupa soal materi bangun datar, khususnya luas persegi, luas persegi panjang dan luas segitiga. Tes kreativitas pemecahan masalah bertujuan untuk mengetahui kreativitas pemecahan masalah siswa, sehingga soal tes dirancang untuk dapat menggali tiga komponen indikator kreativitas, yaitu kefasihan, kebaruan, dan fleksibilitas. Untuk meyakinkan jawaban siswa, dilakukan klarifikasi dengan wawancara secara langsung kepada siswa berdasarkan jawaban yang telah ditulis. Untuk melakukan wawancara disusun pedoman wawancara. Pedoman wawancara dibuat secara terstruktur untuk menginvestigasi karakteristik kreativitas siswa ketika menyelesaiakan masalah. Indikator kreativitas yang diselidiki, meliputi kefasihan, fleksibilitas, dan kebaruan. Investigasi karakteristik kreativitas pemecahan masalah ini dilakukan pada mengerjakan penyelesaian masalah. Metode wawancara yang digunakan adalah wawancara klinis terstruktur, dengan ketentuan: a) Pertanyaan wawancara yang diajukan disesuankan dengan kondisi pemecahan masalah yang dilakukan siswa (tulisan maupun penjelasannya). b)Pertanyaan yang diajukkan tidak harus sama, tetapi memuat inti permasalahan yang sama. c)Apabila siswa mengalami kesulitan dengan pertanyaan tertentu, mereka akan didorong merefleksi atau diberikan pertanyaan yang lebih sederhana tanpa menghilangkan inti permasalahan.

Angket digunakan untuk mengetahui respon siswa secara tertulis terhadap penerapan pemecahan masalah menggunakan metode what's another way. Pernyataan di angket terdiri dari sepuluh butir pertanyaan. 
Data kreativitas pemecahan masalah dianalisis merujuk pada indikator kreativitas, meliputi: kefasihan, fleksibilitas dan kebaruan. Langkah pertama dilakukan penskoran terhadap hasil tes kreativitas dan hasil wawancara dengan merujuk pada Tabel 2. Langkah kedua, dilakukan pembobotan pada setiap skor yang diperoleh pada langkah pertama. Mengacu pada tingkat kesulitan dari masing-masing indikator, skor kefasihan diberi bobot 1, skor fleksibilitas diberi bobot 2, dan skor kebaruan diberi bobot 3. Apabila tiap-tiap indikator memperoleh skor tertinggi yaitu 3, maka bobot tertinggi diperoleh 18 , $((3 \times 1)+(3 \times 2)+(3 \times 3)=18)$. Selanjutnya menentukan kualitas kreativitas dengan merujuk pada Tabel 3 .

Tabel 2. Pedoman Penskoran Tahap Mengerjakan Pemecahan Masalah

\begin{tabular}{ll}
\hline Kefasihan & \\
\hline Skor 3: & $\begin{array}{l}\text { Siswa menujukkan cara mengerjakan pemecahan masalah yang } \\
\text { bermacam-macam dan semua betul. (lebih dari dua macam). }\end{array}$ \\
& $\begin{array}{l}\text { Siswa menujukkan satu atau dua macam cara mengerjakan } \\
\text { pemecahan masalah dan semuanya betul. Atau siswa } \\
\text { menujukkan lebih dari dua macam cara mengerjakan }\end{array}$ \\
& $\begin{array}{l}\text { pemecahan masalah, tetapi ada sebagian yang dituliskan/ } \\
\text { disebutkan salah. }\end{array}$
\end{tabular}

Skor 1: Siswa menunjukkan satu atau dua macam cara mengerjakan pemecahan masalah, tetapi ada sebagian cara mengerjakan yang dituliskan/disebutkan salah.

Skor 0: Siswa tidak menujukkan cara mengerjakan pemecahan masalah dengan atau menujukkan satu atau dua cara mengerjakan pemecahan masalah, tetapi semuanya bernilai salah.

Fleksibilitas

Skor 3: Siswa dapat mengubah cara pemecahan masalah satu ke cara pemecahan lain yang berbeda sebanyak lebih dari dua macam cara dan semuanya betul.

Skor 2: Siswa dapat mengubah cara mengerjakan pemecahan masalah satu ke cara lain yang berbeda sebanyak satu atau dua. Atau siswa dapat mengubah cara mengerjakan pemecahan masalah satu ke cara lain yang berbeda sebanyak lebih dari dua, tetapi ada sebagian cara yang dituliskan/disebutkan salah.

Skor 1: Siswa dapat mengubah mengerjakan pemecahan masalah satu ke cara lain yang berbeda sebanyak satu atau dua, tetapi hanya sebagian cara yang dapat dituliskan/disebutkan dengan betul.

Skor 0: Siswa tidak dapat mengubah cara mengerjakan pemecahan masalah satu ke cara lain yang berbeda atau dapat mengubah Kualitas

Sangat

fasih

Fasih cara mengerjakan pemecahan masalah satu secara lain berbeda, tetapi bernilai salah.

Kebaruan

Skor 3: $\quad$ Siswa menujukkan cara mengerjakan pemecahan masalah yang Sangat baru berbeda-beda (sebanyak lebih dari dua) dan menuliskan/menyebutkan dengan betul. Atau menujukkan satu atau lebih cara mengerjakan pemecahan masalah yang tidak biasa dilakukan oleh individu (siswa pada tahap perkembangannya atau tingkat pengetahuannya.

Sangat

fleksibel

Fleksibel

Kurang

fleksibel

Tidak

fleksibel

Skor 2: Siswa menujukkan cara mengerjakan pemecahan masalah yang Baru 


\begin{tabular}{ll}
\hline & $\begin{array}{l}\text { berbeda-beda (sebanyak satu atau dua) dan } \\
\text { menuliskan/menyebutkan dengan betul. Atau siswa } \\
\text { menujukkan cara mengerjakan pemecahan masalah yang } \\
\text { berbeda-beda (sebanyak lebih dari dua), tetapi ada sebagian } \\
\text { yang dituliskan/disebutkan salah. } \\
\text { Skor 1: } \\
\text { Siswa menujukkan cara mengerjakan pemecahan masalah yang Kurang } \\
\text { berbeda-beda (sebanyak satu atau dua), tetapi hanya dapat baru } \\
\text { menuliskan/menyebutkan sebagian yang betul. Atau siswa } \\
\text { menujukkan satu cara mengerjakan pemecahan masalah yang } \\
\text { tidak biasa dilakuakn oleh individu (siswa) pada tahap } \\
\text { perkembangannya atau tingkat pengetahuannya, tetapi hanya } \\
\text { dapat menuliskan/menyebutkan sebagian yang betul. } \\
\text { Siswa tidak menujukkan cara mengerjakan pemecahan Tidak baru } \\
\text { masalah yang berbeda-beda,a tau tidak menujukkan satu cara } \\
\text { mengerjakan pemecahan masalah yang tidak bisa dilakukan } \\
\text { oleh individu (siswa) pada tahap perkembangannya atau } \\
\text { tingkat pengetahuannya. Atau menujukkan cara mengerjakan } \\
\text { pemecahan masalah yang berbeda-beda, tetapi bernilai salah. }\end{array}$ \\
\hline
\end{tabular}

Tabel 3. Kualitas Kreativitas Pemecahan Masalah

\begin{tabular}{lc}
\hline \multicolumn{1}{c}{ Kualitas Kreativitas } & Skor Berbobot (SB) \\
\hline Kreativitas tinggi & $\mathrm{Sb} \geq 16$ \\
Kreativitas sedang/cukup & $10 \leq \mathrm{Sb} \leq 15$ \\
Kreativitas rendah & $4 \leq \mathrm{Sb} \leq 9$ \\
Kreativitas sangat rendah & $0 \leq \mathrm{Sb} \leq 3$ \\
\hline
\end{tabular}

Hasil angket dianalis dengan mengelompokkan respon siswa pada setiap pernyataan dalam angket menjadi respon positif dan respon negatif. Respon siswa dikatakan positif apabila banyaknya siswa yang memberi respon "sangat setuju" dan "setuju" persentasenya lebih besar daripada respon "tidak setuju" dan "sangat tidak setuju". Respon siswa dikatakan negatif apabila banyaknya siswa yang memberikan respon "sangat setuju" dan "setuju' persentasenya lebih kecil daripada respon "tidak setuju" dan "sangat tidak setuju". Kesimpulan secara keseluruhan dari pernyataan dalam angket adalah apabila respon siswa lebih banyak yang positif terhadap pemecahan masalah melalui metode what's another way. Apabila terjadi sebaliknya maka siswa dikatakan memberikan respon negatif terhadap pemecahan masalah melalui metode what's another way.

\section{HASIL DAN PEMBAHASAN}

Dari hasil penelitian yang telah dilaksanakan di SMP Negeri 2 Semanding pada tahun pelajaran 2010/2011, diperoleh data yang selanjutnya dianalisis sehingga dihasilkan data yang valid. Subjek dalam penelitian ini sebanyak 6 siswa yaitu SD, SM, WN, KD, MS, dan DF. Subjek yang dipilih dalam penelitian ini berdasarkan tingkat kemampuan yang berbeda-beda yaitu pandai, sedang, dan kurang pandai. Subjek dipilih dengan pertimbangan dapat mengkomunikasikan pendapat/jalan pikirannya baik secara lisan maupun tulisan. Setelah data di analisis, diperoleh data yang valid dari keenam subjek. Data yang diperoleh akan disajikan dalam gambar profil kreativitas pemecahan masalah. Adapun hasil penskoran dapat disajikan pada Tabel 4 berikut. 
Tabel 4. Distribusi Hasil Penskoran Skor Berbobot 6 Subjek

\begin{tabular}{|c|c|c|c|c|c|c|c|c|c|c|c|c|c|c|c|c|c|c|}
\hline \multirow{2}{*}{ Indikator } & \multicolumn{3}{|c|}{ SD * } & \multicolumn{3}{|c|}{ SM * } & \multicolumn{3}{|c|}{$\mathrm{WN} * *$} & \multicolumn{3}{|c|}{ KD ** } & \multicolumn{3}{|c|}{ MS *** } & \multicolumn{3}{|c|}{ DF*** } \\
\hline & SI & SII & SIII & SI & SII & SIII & SI & SII & SIII & SI & SII & SIII & SI & SII & SIII & SI & SII & $\bar{S}$ \\
\hline Kefasihan & 3 & 3 & $\overline{3}$ & 2 & 3 & 3 & 1 & 2 & 3 & 1 & 2 & 3 & 1 & 2 & 2 & 1 & 2 & \\
\hline Kebaruan & 6 & 6 & 9 & 6 & 6 & 6 & 3 & 3 & 3 & 3 & 3 & 3 & 0 & 0 & 3 & 0 & 0 & \\
\hline Fleksibel & 4 & 6 & 6 & 4 & 4 & 6 & 2 & 2 & 4 & 2 & 2 & 2 & 0 & 2 & 2 & 2 & 0 & \\
\hline$\overline{\text { SB }}$ & 13 & 15 & $\overline{18}$ & 12 & 13 & 15 & 6 & 7 & 10 & 6 & 7 & 8 & 1 & 4 & 7 & 3 & 2 & \\
\hline
\end{tabular}

Keterangan: $* \quad=$ Subjek dengan kemampuan pandai siklus I, Siklus II, Siklus III

$* *$ = Subjek dengan kemampuan sedang

$* * *=$ Subjek dengan kemampuan kurang pandai

$\mathrm{SB}=$ Skor Berbobot

Berdasarkan Tabel 4 dapat terlihat jumlah skor berbobot skor berbobot dari tiap siklus dari 6 subjek. Dari dua data yang diperoleh, maka dapat dibuat gambar profil kreativitas pemecahan masalah tiap-tiap siklus pada tiap-tiap kelompok dengan kemampuan yang berbeda-beda yaitu pandai, sedang dan kurang pandai.

\section{Subjek dengan Kemampuan Pandai}

Berdasarkan data yang diperoleh dapat dibuat grafik profil kreativitas pemecahan masalah subjek dengan tingkat kemampuan pandai, yaitu SD dan SM.

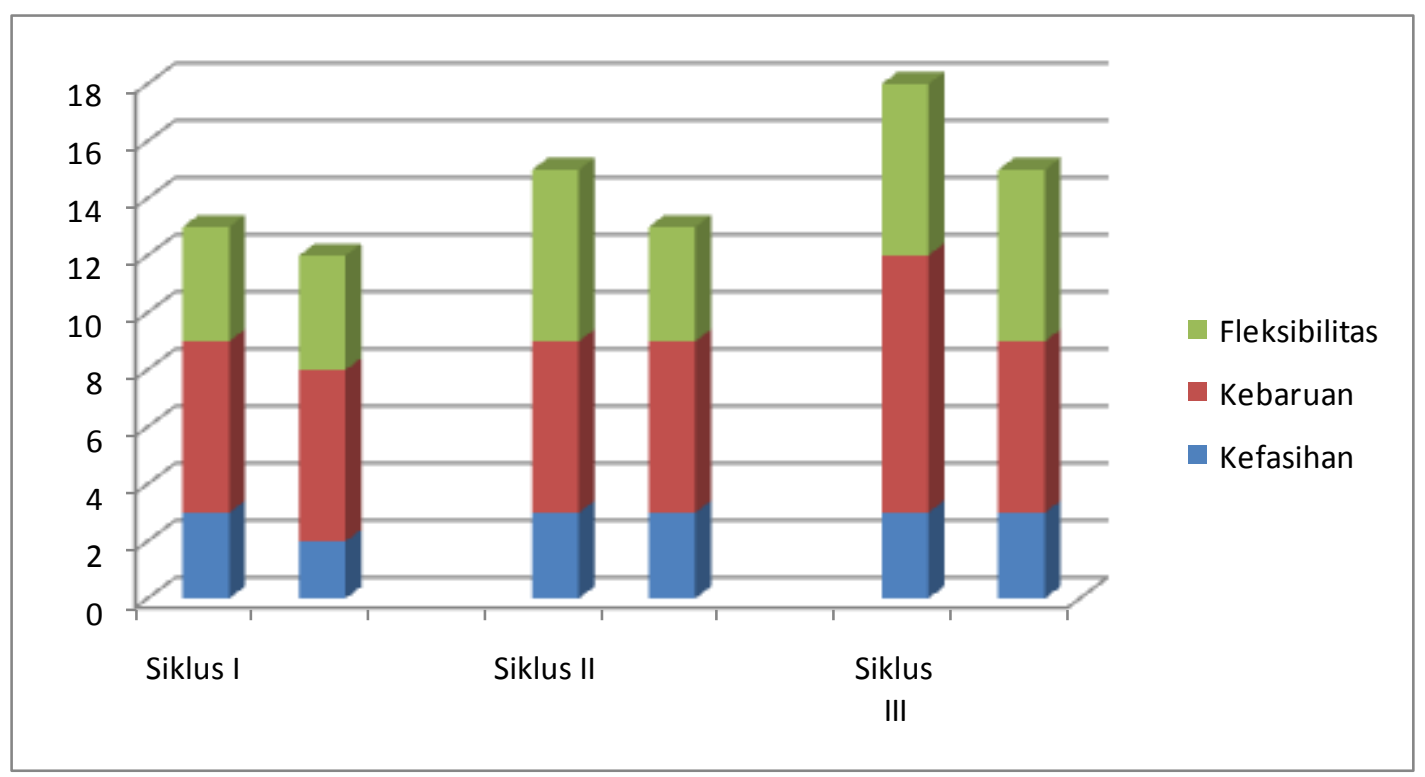

Gambar 1. Profil Kreativitas Pemecahan Masalah Subjek Pandai

Berdasarkan Gambar 1. dapat terlihat skor berbobot yang diperoleh tiap subjek dengan tingkat kemampuan pandai, adalah sebagai berikut:

a) Subjek 1 adalah SD, pada siklus I jumlah skor berbobot yang diperoleh adalah 13, pada siklus II jumlah skor berbobotnya adalah 15 dan pada siklus III jumlah skor berbobotnya adalah 18 .

b) Subjek 2 adalah SM, pada siklus I jumlah skor berbobot yang diperoleh adalah 12, pada siklus II jumlah skor berbobotnya adalah 13 dan pada siklus III jumlah skor berbobotnya adalah 15 . 
Berdasarkan Gambar 1 terlihat skor berbobot yang diperoleh pada tiap-tiap subjek dengan tingkat kemampuan pandai, kreativitas dalam pemecahan masalah mengalami peningkatan setelah diterapkan metode what's another way dan kreativitas subjek dengan kemampuan pandai memiliki kualitas kreativitas cenderung sedang.

\section{Subjek Dengan Kemampuan Sedang}

Berdasarkan data yang diperoleh dapat dibuat grafik profil kreativitas pemecahan masalah subjek dengan tingkat kemampuan sedang, yaitu WN dan KD.

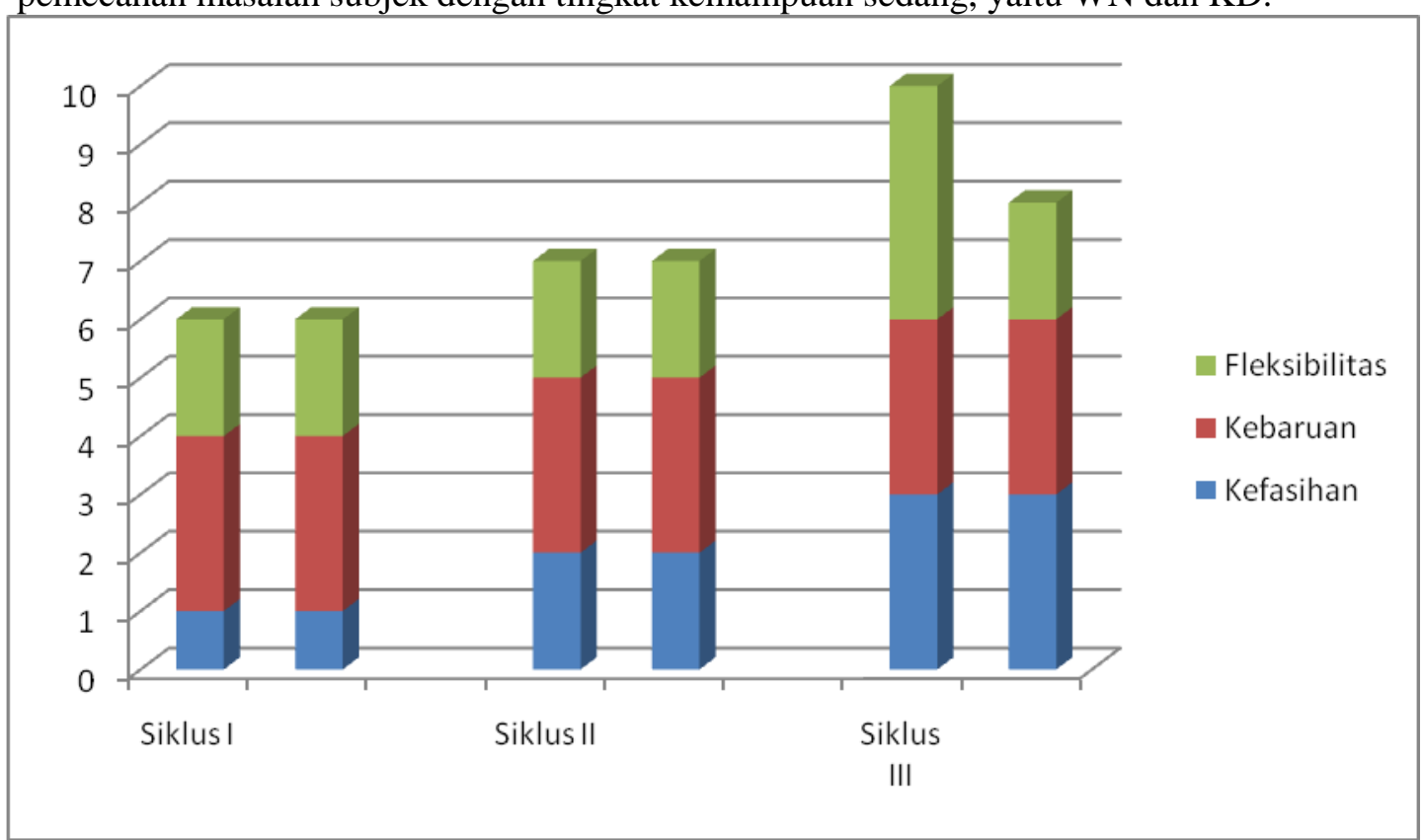

Gambar 2. Profil Kreativitas Pemecahan Masalah Subjek Kemampuan Sedang

Berdasarkan Gambar 2 dapat terlihat skor berbobot yang diperoleh tiap subjek dengan tingkat kemampuan sedang, adalah sebagai berikut:

a) Subjek 3 adalah WN, pada siklus I jumlah skor berbobot yang diperoleh adalah 6, pada siklus II jumlah skor berbobotnya adalah 7, dan pada siklus III jumlah skornya adalah 10 .

b) Subjek 4 adalah KD, pada siklus I jumlah skor berbobot yang diperoleh adalah 6 , pada siklus II jumlah skor berbobotnya adalah 7, dan pada siklus III jumlah skornya adalah 8 .

Berdasarkan Gambar 2 terlihat skor berbobot yang diperoleh pada tiap-tiap subjek dengan tingkat kemampuan sedang, kreativitas dalam pemecahan masalah mengalami peningkatan setelah diterapkannya metode what's another way dan kreativitas subjek dengan kemampuan sedang memiliki kualitas kreativitas cenderung rendah.

\section{Subjek Dengan Kemampuan Kurang Pandai}

Berdasarkan data yang diperoleh dapat dibuat grafik profil kreativitas pemecahan masalah subjek dengan tingkat kemampuan kurang pandai, yaitu MS dan DF. 


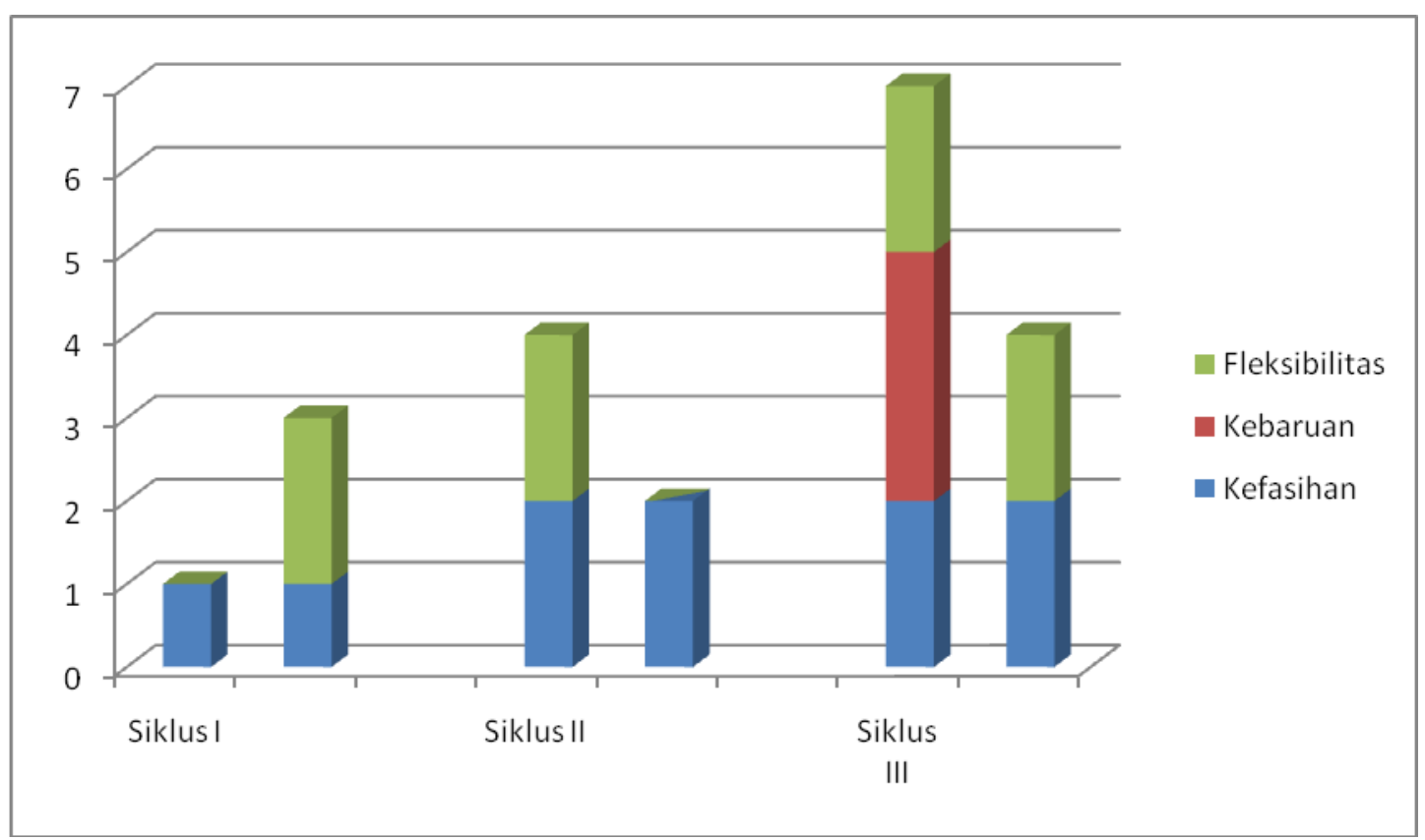

Gambar 3. Profil Kreativitas Pemecahan Masalah Subjek Kurang Pandai

Berdasarkan Gambar 3 dapat terlihat skor berbobot yang diperoleh tiap subjek dengan tingkat kemampuan kurang pandai, adalah sebagai berikut:

a) Subjek 5 adalah MS, pada siklus I jumlah skor berbobot yang diperoleh adalah 1, pada siklus II jumlah skor berbobotnya adalah 4, dan pada siklus III jumlah skor berbobotnya adalah 7 .

b) Subjek 6 adalah DF, pada siklus I jumlah skor berbobot yang diperoleh adalah 3, pada siklus II jumlah skor berbobotnya adalah 2, dan pada siklus III jumlah skor berbobotnya adalah 6 .

Berdasarkan Gambar 3 skor berbobot yang diperoleh pada tiap-tiap subjek dengan tingkat kemampuan kurang pandai. Subjek dengan kemampuan kurang pandai kreativitas dalam pemecahan masalah mengalami peningkatan setelah diterapkannya metode what's another way dan kreativitas subjek dengan kemampuan kurang pandai memiliki kualitas kreativitas cenderung rendah.

Berdasarkan gambar-gambar di atas dapat terlihat skor berbobot yang diperoleh pada kualitas kreativitas 6 subjek, subjek dengan tingkat kemampuan pandai mengalami peningkatan setelah diterapkannya metode what's another way. Subjek dengan tingkat kemampuan sedang juga mengalami peningkatan dan subjek dengan tingkat kemampuan kurang pandai juga mengalami peningkatan. Berdasarkan data tersebut, dapat disimpulkan bahwa subjek yang pandai, sedang, dan kurang pandai kreativitas siswa dapat meningkat setelah diterapkan metode what's another way pada pemecahan masalah. Sedang, kualitas kreativitas untuk subjek dengan kemampuan pandai cenderung sedang, subjek dengan kemampuan sedang cenderung rendah, dan subjek dengan kemampuan kurang pandai kreativitasnya cenderung rendah.

\section{Respon Siswa Terhadap Kegiatan Pembelajaran}

Respon siswa terhadap kegiatan pembelajaran diketahui melalui angket yang telah diisi oleh siswa pada akhir dari keseluruhan proses pembelajaran. Berikut ini data respon siswa terhadap kegiatan pembelajaran yang terdapat pada tabel dibawah ini. 
Tabel 5. Angket Respon Siswa terhadap Kegiatan Pembelajaran

\begin{tabular}{|c|c|c|c|c|c|}
\hline \multirow{2}{*}{ No } & \multirow{2}{*}{ Butir Angket } & \multicolumn{4}{|c|}{ Respon Siswa (\%) } \\
\hline & & SS & $\mathrm{S}$ & TS & STS \\
\hline 1 & $\begin{array}{l}\text { Memecahkan soal sendiri menyenangkan karena } \\
\text { saya dapat mencoba dan menggunakan ide sendiri }\end{array}$ & 48,78 & 51,22 & - & - \\
\hline 2 & $\begin{array}{lccc}\text { Memecahkan soal dengan } & \text { banyak } & \text { cara } \\
\text { menyebabkan materi pelajaran } & \text { maupun } & \text { cara } \\
\text { menyelesaikan soal mudah diingat. } & & \end{array}$ & 31,70 & 60,98 & 7,32 & - \\
\hline 3 & $\begin{array}{l}\text { Saat mengikuti pembelajaran dengan cara yang } \\
\text { dilakukan, saya yakin akan dapat memecahkan soal } \\
\text { dengan banyak cara }\end{array}$ & 41,46 & 48,78 & 9,76 & - \\
\hline 4 & $\begin{array}{lccr}\text { Memecahkan } & \text { soal } & \text { dengan banyak cara } \\
\text { mengharuskan } & \text { saya } & \text { memahami } & \text { soal-soal } \\
\text { sebelumnya. } & & & \end{array}$ & 26,83 & 73,17 & - & - \\
\hline 5 & $\begin{array}{l}\text { Memecahkan soal dengan banyak cara saya } \\
\text { terdorong lebih kreatif dalam memecahkan masalah }\end{array}$ & 48,78 & 51,22 & - & - \\
\hline 6 & $\begin{array}{l}\text { memecahkan soal dengan banyak cara, saya } \\
\text { terdorong memikirkan untuk menjawab soal dengan } \\
\text { cara-cara berbeda }\end{array}$ & 36,58 & 56,10 & 7,32 & - \\
\hline 7 & $\begin{array}{l}\text { Memecahkan soal membatu saya menghubungkan } \\
\text { matematika dengan materi sebelumnya atau hal-hal } \\
\text { lain dalam kehidupan sehari-hari }\end{array}$ & 36,58 & 58,54 & 4,88 & - \\
\hline 8 & $\begin{array}{l}\text { Tugas memecahkan soal memudahkan saya } \\
\text { memahami materi yang telah dijelaskan di kelas }\end{array}$ & 26,83 & 68,29 & 4,88 & - \\
\hline 9 & $\begin{array}{l}\text { Memecahkan soal mendorong saya untuk lebih giat } \\
\text { mempelajari materi sebelumnya }\end{array}$ & 53,66 & 43,90 & 2,44 & - \\
\hline 10 & $\begin{array}{l}\text { Memecahkan masalah merupakan tugas yang } \\
\text { menarik dan merupakan cara mengajar guru yang } \\
\text { baru }\end{array}$ & 53,66 & 43,90 & 2,44 & - \\
\hline & $\begin{array}{ll}=\text { sangat setuju } & \text { TS }=\text { tidak setuju } \\
=\text { setuju } & \text { STS }=\text { sangat tidak }\end{array}$ & & & & \\
\hline
\end{tabular}

Dari Tabel 5, dapat dilihat persentase respon siswa tiap nomor pada pernyataan butir angket yang telah diisi siswa diakhir seluruh proses pembelajaran. Sesuai dengan analisis data angket, respon siswa dikatakan positif apabila jumlah persentase siswa yang meyatakan "sangat setuju" dan "setuju" lebih besar daripada persentase siswa yang menyatakan "tidak setuju" dan "sangat tidak setuju". Dari hasil analisis data angket dapat dilihat jumlah persentase pada siswa yang menyatakan "sangat setuju" dan "setuju" lebih besar daripada jumlah persentase siswa yang menyatakan "tidak setuju" dan "sangat tidak setuju". Jadi, dapat disimpulkan dari hasil analisis angket bahwa respon siswa positif terhadap kegiatan pembelajaran.

\section{PENUTUP} sebagai berikut:

Berdasarkan hasil penelitian yang dilaksanakan, diperoleh kesimpulan 
1. Penerapan metode what's another way dapat meningkatkan kreativitas siswa dalam memecahkan masalah bangun datar siswa kelas VII SMP. Hal ini dapat dilihat dari hasil analisis tiap subjek, sebagai berikut:

a) Subjek dengan tingkat kemampuan pandai, kreativitas dalam memecahkan masalah meningkat setelah diterapkan metode what's another way dan kreativitas subjek dengan kemampuan pandai memiliki kualitas kreativitas cenderung sedang.

b) Subjek dengan tingkat kemampuan sedang, kretivitas dalam pemecahan masalah meningkat setelah diterapkan metode what's another way dan kreativitas subjek dengan kemampuan sedang memiliki kualitas kreativitas cenderung rendah.

c) Subjek dengan tingkat kemampuan kurang pandai, kreativitas dalam pemecahan masalah meningkat setelah diterapkan metode what's another way dan kreativitas subjek dengan kemampuan kurang pandai memiliki kualitas kreativitas cenderung rendah.

2. Secara umum siswa mempunyai respon positif terhadap pembelajaran pemecahan masalah melalui metode what's another way.

\section{DAFTAR PUSTAKA}

Cooney, T.J, Davis, E.J, Henderson, K.B. 1975. Dynamics of Teaching Secondary School Mathematics. Boston: Houghton Mifllin Company.

Davis, Edward J. \& McKillip, William D. 1980. Improving Story Problem Solving in Elementary School Mathematics. Dalam Krulik, Stephen \& Reys, Robert E. (Ed) Problem Solving in School Mathematics. Reston: NCTM. Yearbook 1980

Furinghetti, Fulvia \& Morselli, Francesca. 2004. Reflections on Creativity: The Case of a Good Problem Solver. Download 28 Februari 2008

Hudoyo, Herman. 2003. Kurikulum Matematika dan Pelaksanannya di Depan Kelas. Surabaya : Usaha Nasional.

Hurlock, Elizabeth B. 1999. Perkembangan Anak Jilid 2 (Alih Bahasa: dr Med Meitasari Tjandrasa). Jakarta: Erlangga.

Krulik, Stephen, and Rudnick, Jesse A. 1999. Innovative Taks to Improve Critical and Creative Thinking Skills. Dalam Stiff, Lee V, Curcio, Frances R. Ceds. Developing Mathematical Reasoning in National Council of Theacher of Mathematics.

Krutetskii, V.A 1976. The Psychology of Mathematical Abilities in School children. Chicago: The University of Chicago Press.

LeBlanc, John F., Proudfit, Linda \& Putt, Ian J. 1980. Teaching in Problem Solving in the Elementary School. Dalam Krulik, Stephen \& Reys, Robert E. (Ed) Problem Solving in School Mathematics. Reston, Virginia: NCTM Yearbook 1980.

Marzano, R.J, Brandt, R.S., Hughes, C.S., Jones, B.F., Presseisen, B.Z., Rankin, S.C., \& Sohor, C. 1988. Dimention of Thinking: A framework for Curriculum and Instruction. Alexandria, Virginia: Association for Supervision and Curriculum Development.

Muhadjir, Noeng. 1990. Metodologi Penelitian Kualitatif. Yogyakarta: Rake Sarasin.

Munandar, S.C. Utami. 1999. Pengembangan Kreativitas Anak Berbakat. Jakarta: Depdikbud dan Rineka Cipta.

Orton, Anthony. 1992. Learning Mathematics. Issues, Theory and Classroom Practice. Second Edition. Printed and bound in Great Britain by Dotesios Ltd. Trowbrigde, Wilts. 
Polya, G. 1973. How to Solve It. Second Edition. Princeton, New Jersey: Princeton University Press.

Polya, G. (1980) On Solving Mathematical Problem in High School. Dalam Krulik, Stephen \& Reys, Robert E. (Ed) Problem Solving in School Mathematics. Reston, Virginia: NCTM Inc.

Ruseffendi, E.T. 2004. Pengantar Kepada Guru Mengembangkan Kopetensinya dalam Pengajaran Matematika. Bandung : Tarsito.

Schoenfeld, Alan H. 1985. Mathematical Problem Solving. New York: Academic Press. Inc.

Winataputra, Udin Saripudin. 2010. Implementasi Kebijakan Nasional Pembangunan Karakter Bangsa melalui Pendidikan Karakter (Konsep, Kebijakan, dan Kerangka Programatik). http://kisyani.files.wordpres.com/2010/07/makalah1.pdf. Diakses 9 Mei 2011.

Warli. 2007. Meningkatkan Kemampuan Berpikir Kreatif melalui Pembelajaran dengan Pendekatan Open-Ended. Tidak dipublikasikan.

Warli. 2010. Profil Kreativitas Siswa yang Bergaya Kognitif Reflektif dan Siswa yang Bergaya Kognitif Implusif dalam Memecahkan Masalah Geometri. Disertasi Tidak di Publikasikan. Surabaya : UNESA.

Warli. 2011. Improving the Creativity of Students in Proving the Validity of Arguments Through Learning Strategy "What's Another Way". Hasil Penelitian. Disajikan dalam International Seminar and the Fourth National Conference on Mathematics Education Department of Mathematics Education, Yogyakarta State University, 21-23 July 2011 